\title{
An Angle of Seeing: \\ Pornography and Profanity as Pharmakon in Darko's Beyond the Horizon and The Housemaid
}

\author{
Philomena Abeka \\ Kwame Nkrumah University of Science and Technology, Ghana \\ E-mail: philookyeso@yahoo.ca \\ Charles Marfo (Corresponding author) \\ Kwame Nkrumah University of Science and Technology, Ghana \\ E-mail: cmarfo@gmail.com \\ Lucy Bonku \\ Kumasi Polytechnic
}

Doi:10.7575/aiac.alls.v.5n.2p.108

Received: 17/02/2014

URL: http://dx.doi.org/10.7575/aiac.alls.v.5n.2p.108

Accepted: 05/04/2014

\begin{abstract}
What strategies does a female writer develop to overcome her anxiety of correcting the moral decadence in her society? Inappropriate as the use of pornography and profanity must have always seemed, Amma Darko has managed to put some positive and meritorious spins on them and seriously use them. In this paper, we examine how in two books, Beyond the Horizon and The housemaid, Amma Darko strategizes to use pornography and profanity as remedies; that moral cleansing can be achieved by the strategic use of immoral pictures and language. This strategy traces back to Aristotle's age-old prescription that catharsis must be the final achievement of curtailing tragedy. In this paper, therefore, we observe how the use of pornography and profanity can contribute to the cleansing of a society whose moral fibre is engulfed in decadence. Furthermore, a near-laser analysis of the relationships between (catharsis-based) pharmakon, pornography and profanity as given in the books in discussion is done.
\end{abstract}

Keywords: pornography and profanity, pharmakon, carthasis, moral decadence

\section{Introduction}

There is a certain primordial logic in claiming that the use of indecent pictures and indecent language - specifically noted here as pornography and profanity respectively - communicate directly and sharply to the inner being, due to varied reactions these produce in our psyche. CARE International defines pornography as the 'explicit representation of sexual activity in print or on film to simulate erotic rather than aesthetic or emotional feelings'. ${ }^{i}$ Williams (1981), for example, also sees it as a sexually explicit material (verbal or pictorial) that is primarily designed to produce sexual arousal in viewers. Profanity on the other hand has been variously defined as language or even a gesture that is considered vulgar, obscene or offensive; language that demonstrates irreverence or disrespect towards groups of people or something that point to them and they can relate to, often times emotionally, for instance religious beliefs.

Amma Darko, a female writer, came into the literary scene in the early nineteen nineties (1990s). Consistently, she has sought to portray in her novels those practices that bring embarrassment to her shared gender and to use these same novels to teach acceptable morals that bring recognition and appreciation to women. Interestingly, we identify in these novels a near problematic display of pornography and profanity. That is, considering the definitions of the terms given above, certain lines in her novels could be described as pornographic and profanity. This communicates a kind of paradox, in that, in these same novels, the reader is being preached high moral codes as will be exemplified in some of the following sections. Dako et al. (2006) who has looked at Darko's novels has succinctly captured the thrust of them; i.e. Amma Darko is seen as so concerned with injecting good moral lessons to her readership and that explains why her novels are replete with stories that borders on moral decadence.

Darko's use of pornography and profanity in Beyond the Horizon and The Housemaid exhibits a kind of resistance that manifests in her desire to fight prostitution with its core allies of pornography and profanity. Injecting decency into her shared gender through the use of indecent pictures and language throws into focus the devastating effect that prostitution has on women's image and health. This angle of telling the whole truth about prostitution - i.e., making it look and sound so repulsive to warrant immediate redemptive action - is not only arresting but calculating. Indeed, as presented in Plato's Phaedrus, this angle of seeing and telling reflects Egyptian god of writing's (i.e. Thoth), offer to King Thamus that identified the King's writings as "pharmakon". Pharmakon in that particular case is described as a remedy which can help (in the recollection or protection of) memory. 
Gera (2001: 20-21) observes that one of the ironies in ancient medicinal practices is to inject the sick body with disease causing fluids to restore it to good health. This practice resonates in some modern medicinal practices where some disease causing fluids are used to vaccinate people against being infected by those particular diseases. This is reminiscent of the medicinal metaphor which simultaneously describes writing as violence and cure. Amma Darko's "Beyond the Horizon" and "The Housemaid" are provocative narratives of violations permeated with stark images and unapologetic use of pornography and profanity. The use to which these are put arrests the attention of discerning readers whilst building up anger and alienation towards prostitution.

\title{
2. The Theory of Catharsis and Pharmakon
}

The concept of pharmakon is entrenched in (the theory of) catharsis, which is derived to mean cleansing, purging, or purification. According to Bushman (2007), the first recorded mention of catharsis appeared in Aristotle's Poetics, where he suggests that viewing tragic plays gave people the emotional catharsis from feeling of fear and pity. Also, according to contemporary proponents of the Catharsis theory, acting aggressively or watching aggression, for instance, is an effective way to reduce anger and aggressive feelings (see e.g. Bushman et al. (1999); Powell (n.d.) and Scheff (2001)). The crucial point here then is that an observed 'ill' (or bad behavior) is not necessarily acted on by an agent and for which no one is adversely affected. In other words, that ill - noted as pornography and/or profanity in this paper - may be executed in the actor's or the reader's fantasy, but not in reality.

We suggest that Darko's consistent portrayal of pornography and profanity is for the essence of catharsis-based pharmakon; i.e. a healing or remedy that involves the use of (transient) poisonous or painful effect to the body that is to be healed. With some lines in her two books, we take the position that the ills in society are being purged or healed through the use of pornography and profanity in the following section; i.e. Section 3. Also, in Section 3, we explore the interplay between pornography, profanity, and pharmakon. Section 4 concludes the paper.

\section{Observing the books}

\subsection{Beyond the Horizon}

In Beyond the Horizon, Mara, the naive mother and wife, is transformed into an icon of prostitute first through blackmail and latter through a compelling desire to make too much money to be sent home regularly for the upkeep of her mother and her children. The trajectory in Mara's life is skewed towards a fatal defiance that generates in Mara an obsession to see her family back home enjoy life even if it results in her premature death.

Akobi's determination to marry the sophisticated secretary, Comfort, brings him to contact first Mara, his Ghanaian wife, and then Gittie, his German wife. Mara and Gittie become pawns in the exploitative hands of Akobi, who makes use of the money they make. Mara explains how she was blackmailed by Akobi into accepting prostitution as her profession. That is, after joining her husband in Germany, he (Akobi) 'forces' her to pretend to be his sister so as to ensure peace between Gittie and himself. Shortly after, Akobi makes Mara so vulnerable through a drink laced with a kind of opium that she is helpless even when raped by ten or so men. Mara reckons her ordeal in such a way that we are angered at the severity of the act:

\begin{abstract}
Then something started happening to me. I was still conscious but I was losing control of myself... something was in the wine I had drunk. It made me see double and I felt strange and happy and high... so high that I was certain I could fly free. Then suddenly the room was filled with people, all men, and they were talking and laughing and drinking. And they were completely naked. There must have been at least ten men for what I saw were at least twenty images. Then they were all around me, many hairy bodies, and they were stripping me, fondling me, playing with my body, pushing my legs wide, wide apart. As for the rest of the story, I hope the gods of Naka didn't witness it. (pg. 111)
\end{abstract}

The explicit portrayal of the general abuse of the helpless and, in particular, forceful and countless penetration of her as recounted in this passage may cause arousal in certain but surely a few haughty quarters. However, for critical and noble minds, this kind of explicit sexual matter deepens our anger at the nature of the rape. What was the need in "fondling", "playing" and "pushing her legs wide, wide apart"? Is it to make Mara also enjoy the act or to make the penetration of her easier? We do not blame the many men that committed this act of cowardice and whose action was affront to womanhood, but Akobi. That is, it is the wickedness of Akobi that is clearly portrayed with this use of indecent pictures in this extract. Indeed whilst all this is going on, Akobi, heartless as ever, manages to film the whole act and it was this film that he blackmailed Mara into agreeing to enter into prostitution; as she puts it, "And this is what Osey and Akobi blackmailed me with, so I agreed to do the job at Peepy". (p.115)

It is interesting to note the character of Osey. He is Akobi's friend who brought Mara to join her husband in Germany. When he failed in his attempt at raping Mara in the train, he pulls another strategy and manages to let Mara know that Germany is no clean place when it comes to morals. At Osey's command, the driver who was driving them to his home takes a new direction where Mara is made to witness an obscene poster. Mara's description of this poster reveals Darko's strategic and well-purposed use of pornography as could be read below.

There he issued some more directions to the driver and he took another bend where we were suddenly confronted by a large poster of a ravishingly beautiful white woman, a perfect blonde in a slip, sitting on a stool with legs wide apart, eyes cunningly slanted, tongue calculatingly out and the tip upturned between snow-white teeth, just touching the upper scarlet lip seductively. 
Further down, the right forefinger just grazed her genitals. I turned my eyes away, so ashamed, so disgusted, so scarred and so unsure. (pg. 68)

Mara's description of this prostitute on the poster and her reaction to her shameless posture speak volumes about how morally upright Mara is. The setting, that is Germany, is not shocking. According to a 2009 study by TAMPEP International Foundation ${ }^{\mathrm{ii}}$, Germany's prostitutes' organization HYDRA gives the number of people who work as prostitutes in Germany as about 400,000 with 93\% being female, 3\% transgender and 4\% male. The same study found that $63 \%$ of the prostitutes in Germany were foreigners. This then is really a very permissive environment and we are not shocked that such an indecent poster is advertised. The message, however, is lost on Mara. Through this picture, which we consider as pornography, we are given a foretaste of what awaits Mara. There is foreboding fear created in us and as we listen to Osey's blasphemous commentary below on this posture, we know ahead that Mara is in dangerous hands.

Here are the cream of Germany's Mary Magdalene, Mara. And when you receive blessings here, then fear no foe, for then there ain't no Messiah's feet in this whole wide world you cannot wash! He laughed and laughed and I got more and more confused. (pg. 68-69)

It comes then as no surprise that Osey and Akobi masterminded Mara's rape having realized that indecent pictures alone cannot make her acquiesce. Profanity is also associated with an act that shows disrespect for a religious belief and so Osey's unsolicited commentary shows how disrespectful he is to Christianity for example, so much so that he can even distort scripture and explain biblical truth his own way. In this biblical story (Luke 7:36-38), Mary Magdalene had fully repented of her ways before kissing the Messiah's feet. Indeed, her tears that washed the Messiah's feet all communicate true repentance. What has this got to do with the posture of a prostitute whose aim is to arouse men sexually? The fact that this profane posture is showcased in Germany speaks volumes about the moral decadence there and it only helps us understand why Mara, the once naive girl with a clear moralistic tone, metamorphosed into a girl of porn. As we listen to Mara speak about her perception of her profession, we realize the extent to which she has degenerated even to the extent of using profane language herself to analyze her situation:

I turned face Kaye and said: Kaye, I came here to you and Pee and all the others with thick bushy hair which has now been exotically cut short close to her scalp. My eyebrows have been plucked thin. I have mastered the use of make-up, so that my lips are never without their scarlet taint. And I have received into me the rigid tools of many men and accompanied them on sinful rides through the backdoors of heaven and returned with them back to earth, spent men, I am no longer green and you know it. (pg. 131)

This confession is obviously not coming from a woman who has repented. Indeed, Mara is not eliciting our sympathy. One realizes that the rot has seeped too deep into her that she dares brags about shame. If there is anything clear about her perception about her encounters with men, it is the fact that she portrays it with such masochistic tendencies. In fact she brags about how strong she is when she said she has received into her "rigid" tools of many men. Here, we have an example of a metaphor carried on exaggerative wings; the tools are the penises she allows to enter her vagina. However, an erected penis can never be as hard as a metallic tool. This is where we see her as a braggart. Incidentally, here, Mara is silent about the pain these rigid tools cause her innards. She however tells us this at another place. Eleven pages earlier, Mara tells us in no uncertain terms about the pain she suffers during her treatment as follows.

When I wasn't sleeping with a man, I was crouching over a bucket of steaming hot water diluted with camphor and alum. Sometimes the treatment left me with a numb vagina, so that I even felt nothing when the men were sleeping with me, but it was better than the pain. On top of it all, I was swallowing scores of pain killers and tranquilizers everyday and taking drugs to keep me going. (pg. 120)

Like Cyprian Ekewnsi's Jagua Nana Daughter, ${ }^{\text {ii }}$ Amma Darko gives a very thorough treatment to the issue of prostitution. The pain, the ritual of taking drugs and the loneliness Mara feels are some of the consequences of body merchandising. Mara's plunge into prostitution has nothing to do with an insatiable libido or spiritual enchantment. It has everything to do with Mara's psychological need to experience perpetual abuse from men, be it sexually or physically. Let's listen to Mara summarizing her tragic existence as follows:

\section{At Oves brothel, I have plunged into my profession down to the marrow of my bones. There is no turning back for me now. I am so much a whore not that I can no longer remember or imagine what being a non-whore is. I have problems recollecting what I was before I turned into what I am now. (p. 139)}

Even the marrow of her bones is rotten. With the plenty of money and a five year visa, Mara still sees no escape because money and visa cannot abuse her; it is only men who can abuse her. This, she "enjoys" for it makes her feel masochistic too. For the prostitute, abuse can be sweet and Mara's sexual experiences with men, including the bites, scratches and the verbal abuse all make her feel on top. Here is the pharmakon, the bitter drug administered to readers to take away any sympathy for this complex female character who elicits our condemnation.

Also as a form of pharmakon, the fact is that through the use of pornography and profane language, Amma Darko is able to communicate the dangerous consequences of this profession. One of the most poignant moments in the novel is when Mara informs us that she cannot go a day without sniffing 'snow' (pg. 139). Snow here is the name given to cocaine. Mara is now addicted to cocaine because it enables her to focus on her profession rather than to focus on the 
pains and/or indulge in thoughts about her children back at home. She is 'hooked' on cocaine and she does not hide the consequences as she notes in the following lines.

I am sinking into a place hotter than hell, but I know this. And that is why I have decided that before I sink too deep I will make as much money as possible for my mother and sons back home. (pg. 139)

The tragedy in this confession is sourced from the hyperbolic use of the word 'hell'. Hell's fire, we read, is so hot that it cannot be compared to anything real. For Mara to dare to compare her pain to hell and even make it worse than the pain of hell fire implies the unbearable nature of her plight. If all there is to prostitution is unbearable pain, then no amount of pornography or profanity can make this profession attractive. Here is a rather masterly fashion of using poison to cure poison.

\subsection{The Housemaid}

Whiles in Beyond the Horizon Mara plunges into prostitution because she blackmailed into it (against the background of poverty) and that she ultimately derives a kind of satisfaction from being abused, in The Housemaid, prostitution is carried out for reasons ranging from unfulfilled sexual expectations to desire for financial security. This is clearly explained by Ankomah and Ford (1993); they opine that, in Ghana, sexual intercourse is perceived by some unmarried women as something that is obtained by favour or by bargaining.

In The Housemaid, two women characters, Sekyiwa and her daughter, Tika, are into prostitution not because they are poor, but because of unfulfilled sexual expectations and/or desire for financial security. Against unfulfilled sexual expectations, Sekyiwa for instance enters into sexual contact with young men who can satisfy her sexual desires. After the husband had invested his all to set Sekyiwa up in business, she realizes after the birth of her only child, Tika, that her husband cannot satisfy her in bed. We observe here a paradigm shift in the sense that the received view - i.e. it is men who pay for sex - is radically challenged. Contrary to this expectation, we find a woman paying men to service her need for good sex. Darko tells us the reason behind Sekyiwa's action with the following lines.

So soon after Tika's birth he got Sekyiwa a big shop and filled it with textile prints. By the third year, Sekyiwa had become one of the wealthy market mummies. Young, good-looking male diggers began to vie for her attention. Her husband's libido was waning away so she gave in. She gave them good money, they gave her good sex. Life's satisfaction shone in her eyes. (pg. 13)

Darko here explores one of the causes of promiscuity in some married women. At one point, Sekyiwa's husband mistook Sekyiwa's excitement for love to welcome her to join him enjoy life. Sekyiwa's answer to his husband's invitation reveals once again the use of profane language because she exposes in very derogatory terms her husband's inability to fulfill his sexual roles. Again, this coming from a married woman is really out of place. But to his dismay, Sekyiwa gave him a scornful jeer - Enjoy what life? What life is there to enjoy with a dead penis? Sekyiwa's response begs the question; is sex the ultimate end of marriage? But beyond this question, the response speaks volumes about her promiscuous nature. Indeed, so obsessed was she when it comes to sexual gratification that she elects to have a househelp's care for her only daughter, so she can make more money from her textiles shop rather than make time for her daughter or be the companion her daughter craves for.

In line with pharmakon to the reader, here, through the use of profane language, Amma Darko communicates the dangerous consequences of adultery; sinking into the dungeons of helplessness and the breaking of one's matrimonial home. The breaking of one's matrimonial home is further exhibited by Sekyiwa's relationship with her daughter, Tika. That is, Sekyiwa's obsession to make money and spend with her boy lovers created a barrier between her and Tika.

Also with Tika, we observe that her obsession to make more money was to prove to her-boyfriend that, if she was poor academically, she is good in business. Having received a start-up capital from her mother, Tika immersed herself into her business but realizes too late that there is nothing like clean business. She enters into unscrupulous acquaintances with married men from whom she enjoys various kinds of financial assistance. She gave up Owuraku and settled on four useful steady lovers; Samuel, Raid, Eric and Attui. Samuel, Raid and Eric all have a wife each, wore wedding bands, talked proudly about their wives and children and wanted only lust from Tika. Attui, however, had two wives and twelve children between them and two concubines. So, while Tika saw these men as points of exploitation for her need, ultimately, she was just hound of sexual satisfaction to them, hence the pharmakon, expression of prostitution as advise against sexual exploitation.

In Amma Darko's novels, there is no nostalgia for times gone past; the metaphorical stench from rotten entrails seeps into everything. Clearly, it is not only the major characters whose immoral lifestyles are thrown into focus, but a satellite is thrown on the lifestyles of some of her minor characters as well. For instance in the Housemaid, Attui, one of Tika's numerous influential lovers, insults his wives anytime he is making love to Tika. For some reason, Attui felt that Tika was hoping to become his third wife one day. 'Just keep giving it to me good', he would moan during their lovemaking. Lost in ecstasy, he would insult his wives as stupid old women with dull bodies.

Is Amma Darko providing us with a reason why some men engage in extra marital affairs or is she showcasing Tika as an expert in sex? Well, to all intent and purposes, what comes up clearly from this extract, is the ungrateful and greedy nature of Attui who decides not to be satisfied with his wives and two concubines. The use of the adjectives 'stupid', 'old' and 'dull' to describe the bodies of his wives, does not only reveal his ungratefulness but more especially it 
communicates the narrow-minded nature of Attui, who only considers a fulfilled marriage to be all about good sex. To stretch our understanding to accommodate the import of the phrase 'dull bodies', we need to experience the sentiments which made Oduyoye (1995: 10) to assert that; 'The livingness of the daughters of Anowa is limited to their biology'. Clearly, to a character like Attui, women are valued only when they are able to excite men in bed. Here, we see his narrow-mindedness displayed. A stupid old dull body can cook and take care of children - are they really dull?

From Samuel, the customs officer, Tika is able to smuggle goods from Togo to Ghana. From Raid, the half-caste shop owner, Tika is able to sell her goods fast since he is a shop owner of several outlets. Through Eric, the musician, Tika's name remains on the favored customers list of the Ghana Commercial Bank because the manager is the older brother of Eric. Attui, the factory owner, helps her get good credit rates on the goods she buys. No wonder she sees them more as business partners than lovers. Their business usually lands in Tika's bed and Amma Darko, through the ears of Efia, captures the sexual escapades that go on behind Tika's closed doors. We note one as follows.

Next thing, the key would turn in the lock. And the many times that Efia placed her ear to the keyhole, she heard noises: moans, groans, pants and sighs, and the wild creaking of the bed. (pg. 4a)

The effective use to which onomatopoeia is used in this extract reveals Darko's artistry. She needs not talk about the practice; she picks only the sound that goes with the act and these sounds paints for us various shades of sexual encounters. "The creaking of the bed", the "moans", "pants", "groans" and "sighs" come from a male and female on a bed. Darko's refusal to tell us about the act itself reveals her alienation from a practice she sees as incorrect and abusive, if we consider that such sounds are associated with vigorous sexual encounters.

The use to which pornography and profane language are used in Beyond the Horizon and The Housemaid is completely in keeping with Darko's rebuff of moral decadence. In the case of Akua, a village girl from Kataso, desperate to get to Accra by which ever means possible, sex becomes the only bargaining power which transports her to Accra since she has no money to pay the driver. Darko's description of this rather 'promiscuous barter trade' speaks not only of the decadence to which society has sunk, but most especially the welcoming nature of such decadence in society. Amma Darko renders the scene with such picturesque clarity.

"For nearly three hours, she stood by the roadside asking for a lift. Eventually a contractor's truck stopped for her.

'Where to?' the driver asked curtly.

'Kumasi.'

'You have the money to pay me?'

'No.'

He grunted. 'So you won't pay me?'

Akua unbuttoned her blouse. The driver's eyes blazed with consent. She removed her pants. He grinned, and stopped the truck in a secluded bend.

'But don't make me pregnant,' Akua cautioned.

'I won't,' and he covered her nipples with his lips. He sucked and fondled her body. Akua liked it and did the same for him. When it was over, the rest of the journey continued in stunned silence. The driver dropped her at the railway station four hours later.

'I'm sure you'll find help here,' he assured her and drove away.

Akua did. There were many young girls here working as porters, who had bolted from home to seek greener pastures, just like her." (pg. 30-31)

There is nothing like excitement in this sexual encounter between Akua and the contractor truck's driver. Even in a barter trade, there exists some kind of dialogue depending on how each one feels about what is being offered as a replacement. Dialogue is absent, not because there is nothing to be said, but because the modus operandi is too well understood to entertain any dialogue. There is however a disturbing side to Akua's only request to the driver; "but don't make me pregnant". It shows that Akua is already in the game and knows how well an issue of pregnancy can thwart all her fantastic ideas of making money in the city and later showing off in the village. Why does Amma Darko keep silent on the action the driver took to prevent any pregnancy? Probably the driver is no novice and Amma Darko buttresses our claim in the next few lines, having assured Akua 'I won't' in response to her caution. This driver launches into action, sucking Akua's lips and fondling her body as Akua responds to show her desire. Darko ends her description of the sexual scene on this note.

Obviously, pornography is seen in the description. However, Amma Darko is very cautious not to make it look attractive, and how did she do that? Through abhorrence of it; because the four hour silence that followed the journey communicates a sense of mere usury. Little did the driver care about how penniless Akua will survive in a totally new environment. The insensitive nature of the driver is seen in his last words to her; "I'm sure you'll find help here," he assured her, and drove away. Now, that is the expression of pharmakon; a scene of pornography has been used to dissuade loosening of one's self. 
Tika's househelp, Afia, has also been influenced by her grandmother, whose ambition it is to gain access to Tika's wealth by coercing her to adopt Afia's child 'in the near future'. Even though her plan did not go well with Afia and her mother, she was able to convince them as she goes as follows:

'So I am happy that we are all in agreement now. It means success is assured. Our task will be to make sure that the child never forgets who her real mother is. That way, the wealth will also belong to Efia, and therefore to us all. And we will let it trickle down and spread. We will transform Kataso. The village will hold us in great estimation. May our ancestors see us through!' with dogged determination.

$$
\begin{aligned}
& \text { 'Oh, mother!' admiringly } \\
& \text { 'Oh grandmother!' shyly (pg. 48) }
\end{aligned}
$$

The boldness and ambition displayed by this old woman manifests her greed. By evaluating in monetary terms the worth of her granddaughter's sexual prowess, this old woman has radically disturbed the received view that old women are the repositories of wisdom. Ironically, her diabolical plan was shattered when Afia got pregnant but could not get any responsible man to cater for her, especially at a time when Tika had found out all about her diabolic activities. We agree with Dako et al. (2006) observation that:
“... the central concern of her (Amma Darko) writing: her preoccupation with the body as a site where a relentless and often brutal gendered struggle is taking place...women in Amma Darko's novels use essentially the interwoven survival strategies of fertility, sex, subservience and exploitation." (pg. 37)

Furthermore, it important to note that the grandmother's diabolical plan, which culminates in a fierce tragic end, is an illustration of pharmakon. As has been somehow noted above, traditionally, the grandmother figure has always been associated with wisdom, guidance and protection of life. However, in the Housemaid, the portrayal of Afia's grandmother represents a radical shift from this traditional expectation of the old woman. Readers are well-positioned to analyze and interrogate the received view that demands near reverence for old folks. The pharmakon in presenting the destructive potential of old folks is realizable in the fact that, such a presentation holds the reward of foregrounding the fact that it is about time we apply a near-laser assessment of the action actions of old folks, so that we are not unduly lured by the generally held assumption that whatever they do is right. Indeed, the behavior portrayed by Afia and her grandmother need corrections if womanhood is to be given due reverence.

The activities of this old woman, her daughter and her granddaughter are meant to deploy the extent to which moral decadence has seeped into the fiber of our society. But, as one can also observe as pharmakon, ironically, it is women that stand to lose as we see in the ultimate predicament of Afia. Dako et al. (2006) notes this with the line, “...the bitter irony is that the female self is quite often ultimately diminished and devalued by the nature of the gain in these struggles". By exposing the foils of her shared gender, Amma Darko is using literature as a means to teach women the need to transcend the periphery and reposition themselves through corrective behavior.

\section{Conclusion}

The use to which pornography and profanity are used in Beyond the Horizon and The Housemaid is completely in keeping with Amma Darko's rebuff of moral decadence. For her, prostitution can never be the panacea for female empowerment or need for financial security. She indicates that it is death in itself and there is the need to make it repulsive. A morally upright world destroyed by pornography and profanity (coupled with aspects of them such as prostitution and exploitation) is replaced by the relief of our possibility of experiencing a decent world in a more radical way; i.e. through the repulsive use of the same pornography and profanity. That is pharmakon.

\section{References}

Ankomah, A. and Ford N. (1993). Pre-marital sexual behaviour and its implications for HIV prevention in Ghana. Occasional Paper No. 22, Institute of Population Studies, University of Exeter.

Bushman, B. et al. (1999). Catharsis, aggression and persuasive influence: Self-fulfilling or self-defeating prophecies. Journal of Personality and Social Psychology Vol. 76, No. 3: 367-376.

Bushman, B. (2007). Catharsis of aggression. In R. Baumeister and K. Vohs (Eds.), Encyclopedia of social psychology. (pp. 135-138). Thousand Oaks, CA: SAGE Publications, Inc.

Gera, A. (2001). Three Great African Novelists: Chinua Achebe, Wole Soyinka and Amos Tutuola. New Delhi: Creative Books.

Dako, K, A. Denkabe and H. Yitah. (2006). Pawns and Players: The Women in Amma Darko's Novels. In C. Oppong, Y. P. A. Oppong and I. K. Odotei (Eds.), Sex and Gender in an Era of AIDS: Ghana at the Turn of the Millennium,. Accra: Ghana Sub-Saharan Publishers,

Darko, A. (1995). Beyond the Horizon. London: Heinemann,

Darko, A. (1998). The Housemaid. London: Heinemann,

Oduyoye, M. A. (2004). Daughters of Anowa: Africa Women and Patriarchy. New York: Orbis Books. 
Powell, E. (n.d.). Catharsis in psychology and beyond: A historic overview. Available online <http://primalpage.com/cathar.htm> (18/02/2014).

Scheff, T. J. (2001). Catharsis in Healing, Ritual, and Drama. Lincoln, NE: iUniverse.com.

West, C. (2004/2012). Pornography and censorship. In E. N. Zalta (ed.), The Stanford Encyclopedia of Philosophy, (Fall Edition), http://plato.stanford.edu/archives/fall2013/entries/pornography-censorship/ (12/03/2014).

Williams, B. (Ed.). (1981), Obscenity and Film Censorship: An Abridgement of the Williams Report, New York: Cambridge University Press.

Note:

${ }^{\mathrm{i}} \mathrm{http}: / /$ www.care.org.uk/resources/internet-misuse/what-is-pornography (10/07/2013)

ii $\mathrm{http}: / /$ tampep.eu/documents/Sexworkmigrationhealth final.pdf $(13 / 02 / 2014)$

iii The story of Jagua Nana's Daughter centres on the heroine's traumatic search for her real mother. All the intricacies of family life and relationships are woven into the story. 